Original Article

\title{
Land use Influence on Distribution and Abundance of Herbivores in Samburu-Laikipia, Kenya
}

\author{
Joseph Nderitu Kirathe ${ }^{1,3,4 *}$, John Maina Githaiga ${ }^{3}$, Robert Mutugi Chira ${ }^{3}$, Daniel Rubenstein ${ }^{2,4}$ \\ ${ }^{1}$ School of Natural Resource, Tourism and Hospitality, Maasai Mara University, Kenya \\ ${ }^{2}$ Department of Ecology and Evolutionary Biology, Princeton University, USA \\ ${ }^{3}$ School of Biological Sciences, University of Nairobi, Kenya \\ ${ }^{4}$ Mpala Research Centre, Nanyuki, Kenya
}

Article history:

Received: 18 February 2021

Received in revised form: 16 May 2021

Accepted: 23 June 2021

Available online: 13 July 2021

\begin{abstract}
A B S T R A C T
The distribution and abundance of different wildlife herbivores was studied in Samburu-Laikipia landscape. The study sites included; Mpala and Oljogi, both commercial ranches in Laikipia district; Oldonyiro and Kipsing community areas in Isiolo district; West Gate Conservancy, Ngaroni Community area, Kalama Community area and Sessia-Barsalinga Community area in Samburu district; and Buffalo Spring National Reserve and Samburu National Reserve both protected areas in the landscape. The objectives of the study were: 1) Determine the influence of different land use on seasonal abundances and distribution wildlife species and 2) Examine the influence of livestock, human settlements and water on wildlife species in Samburu-Laikipia landscape. Distance sampling was used to estimate wildlife, livestock and bomas densities. Distance to nearest water was projected from GPS coordinates for both wildlife and livestock sighting using ARCGIS. Our analysis showed non-uniform distributions of wildlife groups across the Samburu-Laikipia ecosystem largely driven by seasonal rainfall patterns and land use types. Like predicted, most wildlife groups occurred in higher abundances on protected areas, Laikipia commercial ranches and community conservancies unlike in community grazing areas in both dry and wet season. However, large grazers increased substantially in community grazing areas over the wet season when livestock grazing was heavy, stimulating growth of short annuals plants of high-quality nutrients. Human activities had negative influences on all wildlife groups. Our findings indicate that the type of land -use influenced herbivore distribution and abundance in Samburu-Laikipia landscape. This suggests that human activities, including pastoralism, in conjunction with season rainfall patterns and land-use shape herbivore distribution and abundance in the area. Conservation strategies for successfully increasing survival of wildlife therefore, requires maintenance of a mixture of land-use types with well controlled and sustainable development.
\end{abstract}

\section{Introduction}

The arid and semi-arid African savannas host diverse assemblage of wildlife species, conspicuous among them are bovids, carnivores and equids with dominant being medium-sized grazing herbivores since the Paleocene (du Toit, 2011). Apparently, these regions are experiencing an increase in human population with varied social-economic activities resulting into different land-use types shaping anthropogenic influences (Meyer and Turner 1992). Arid and semi- arid regions of the world are commonly viewed as overstocked, overgrazed, degraded and unproductive (Vetter, 2005). Increasing human population pressure, modification for other land-uses and bush encroachment contributes to decline in primary productivity, change in vegetation structure and composition. Research evidence demonstrates rainfall is a key factor determining arid and semi-arid savannas productivity in East Africa and elsewhere (Nelson, 2012). The effect of climate change such as global warming and changes in amount and pattern of rainfall in East Africa 
has affected both savanna ecosystem and biodiversity conservation (Lovett et al., 2005). Rapid decline in nutritive value of forage species, particularly protein content, during dry season constrain nutritional requirements for wildlife species. For example, green grass intake and protein content both play a key role in determining the movement, distribution and abundance patterns of migratory wildebeest (Connochaetes taurinus), in the Serengeti National Park ( Holdo et al., 2009). The distribution and abundance of wildlife species is of fundamental importance to ecologists and is central to conservation of these species.

In arid and semi-arid savannas, wildlife populations are threatened by agriculture expansion, human population growth and livestock increase (Ogutu et al., 2016). The compatibility of wildlife conservation in this landscape is highly dependent on the strength of interaction between livestock. humans and wildlife and their impacts on vegetation. Wildlife, human and livestock share land, water, forage, and diseases within these arid and semi-arid regions. In Samburu-Laikipia landscape as in most parts of Kenya rangeland, majority of wildlife populations occurs outside protected areas, where their populations are declining at an alarming rate (Ogutu et al., 2016). These declines occur both in protected areas and outside protected areas due to rapid human population growth (Ogutu et al., 2016). The impact is through expansion of agriculture, settlements, increase in livestock and development of infrastructure resulting to an increase in human wildlife conflicts and changes in resource guilds due to changes in vegetation composition and structure. Changes in land use and land cover causes further deterioration in wildlife and livestock habitats and is exacerbated by climate change and variability, piling enormous pressures on pastoralism, ranching and wildlife conservation in African rangelands and protected areas (Ogutu et al., 2016).

One major land use type in arid and semi-arid regions is livestock keeping either on traditional basis or large-scale ranching enterprises. There is a widespread belief that grazing wildlife, particularly zebras (Equus spp.) and wildebeests compete with cattle for grass in Africa (Prins, 2000). Conversely, some conservationists suggest that resource partitioning minimizes competition, and that livestock production and the conservation of large mammal biodiversity are compatible goals (Hopcraft, 2000). Prins (2000) suggests that although there is considerable niche overlap between wildlife and cattle, competition is largely asymmetrical and diffuse, with cattle having a competitive edge on a number of wildlife species but wildlife having little or no competitive effect on cattle. Odadi et al., (2011) and du Toit (2011) suggest that cattle-wildlife interactions can be both competitive and facilitative, with the net effect determined by the relative densities of each herbivore. This is positive on wildlife living outside conservation areas as they will have to live with livestock but as livestock numbers increase the net effect may tilt against wildlife.
The conservation of wildlife in arid and semi-arid landscapes dominated by human with their livestock is inevitable (du Toit and Cumming, 1999) as most wildlife occurs outside protected areas in the African rangelands. In this context, active management is required, preferably based on some understanding of the ecological processes regulating populations, the extent to which wildlife competes and conflicts with livestock, and the rates at which different land uses influence environmental recourses needed by wildlife, thereby impacting their populations. Understanding the distribution and abundance of wildlife in areas under different land uses will shed more lights on management needs in human dominated and modified landscape. In this study, herbivore wildlife species were censored in the selected study sites of Samburu-Laikipia landscape with the aim of understanding the influences land use change on their population distribution and abundances. Our main objectives were; 1 ) Determine the influence of different land use on seasonal abundances and distribution of herbivore wildlife species, and 2) Examine the influence of livestock, human settlements and water on herbivore wildlife species in Samburu-Laikipia landscape.

\section{Materials and methods}

\subsection{Study area}

The study was conducted between 2009 and 2015 in Samburu-Laikipia landscape located between 360 15'-380 00'E and $0000^{\prime}-1000^{\prime} \mathrm{N}$ covering 15,634 sq. km (Fig. 1). On this landscape there is wide variation in seasonal rainfall, largely affected by altitude and the fact that the Samburu-Laikipia landscape lies on the lee ward side of both the Aberdares range and Mt. Kenya. Study sites located in the south (Laikipia) which receives more rainfall ranging between 400$750 \mathrm{~mm}$ per annum (County Government of Laikipia, 2018) and in the north around Archers post and Wamba town where yearly rainfall averages around $250 \mathrm{~mm}$ per annum (County Government of Samburu, 2018). The climate is hot and dry during the day with cool nights while the mean annual temperature ranges between 160C to 330C (County Government of Samburu, 2018; County Government of Laikipia, 2018). The vegetation communities fall under the 'ecological zone V' consisting largely of bush grassland and wooded grassland (Pratt et al.,1966). The systems represented in the area include alternating savannah mosaic, Acacia-grasslands; Acacia-Commiphora scrubs (Pratt et al., 1966). Large areas of Acacia tortilis wooded grasslands with a ground cover of perennial and annual grasses.

\subsection{Research Design}

We sampled wildlife on four land-use types prevalent in Samburu-Laikipia landscape. These included; i) Laikipia commercial cattle ranches (LRs) with controlled number of livestock which included Mpala Ranch and Oljogi Ranch, ii) Community conservation areas (CCAs) in Laikipia, Samburu 


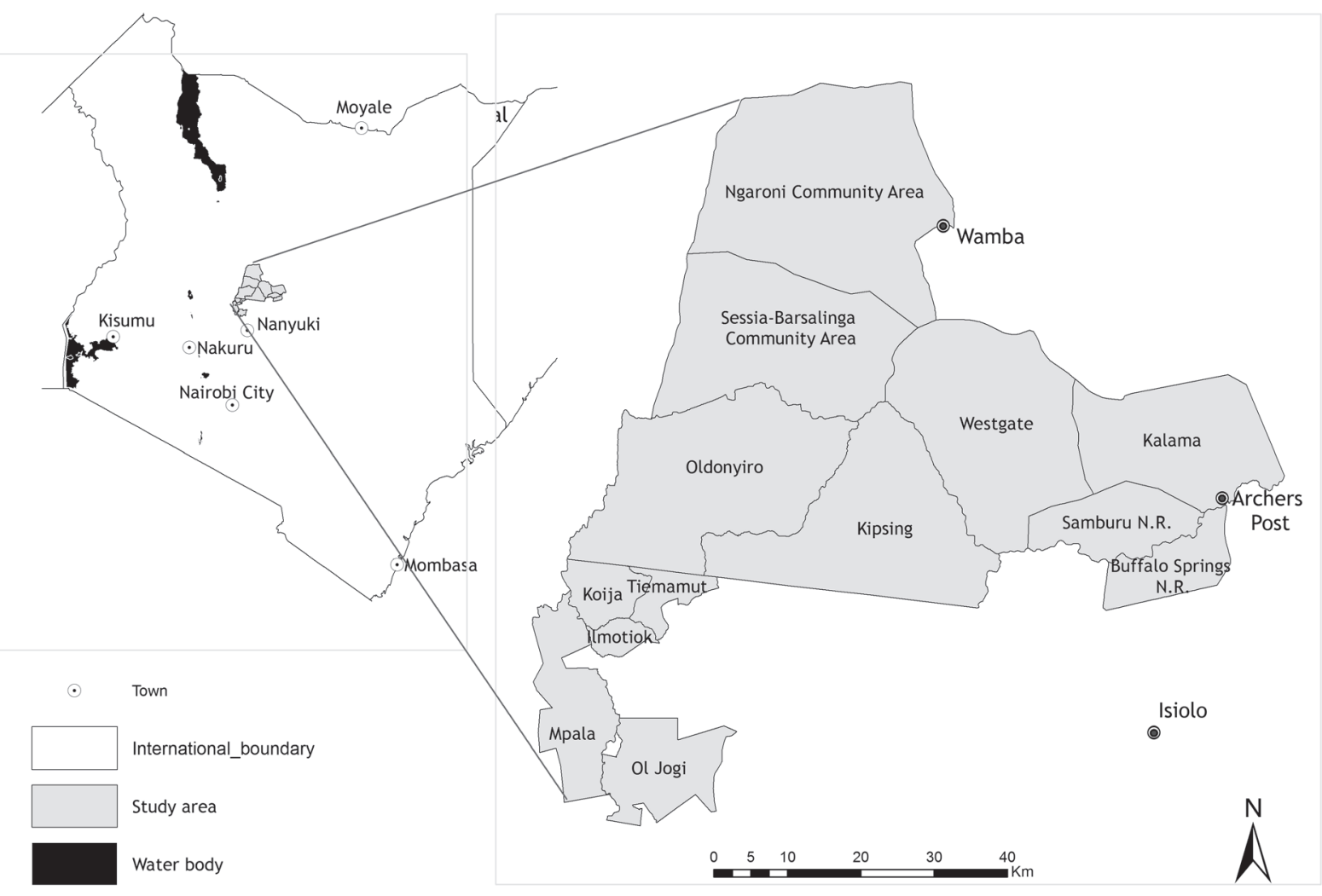

Fig. 1. Map of Kenya showing the location of study area and study sites

and Western side of Isiolo county, iii) Community grazing areas (CGAs) which include community grazing areas in Laikipia, Samburu and Isiolo and iv) Protected areas (PAs) which included Buffalo Springs and Samburu National Reserves. All these land-uses have degrees of human activities uses (Fig. 2).

Wildlife distribution and abundances were assessed using transect lines (Plumptre, 2000). Wildlife sightings was along straight line transects which effectively covered $25-30 \%$ of each of study site. Distance sampling (Thomas et al., 2010) was applied on the transects to determine wildlife distribution and abundance in the study area in both wet and dry weather season. Distance sampling is based on the scenario of animals being distributed spatial-temporally according to a stochastic process with rate parameter D (density). Transects were placed at random or systematically to ensure that animal in the survey strip were uniformly distributed in relation to distance from the transect. Distance sampling rests on four basic assumptions: (i) animals on the transect are always detected; (ii) animal locations are always measured to the point where the animal was first detected; (iii) distances to the animals and angles between the animal and the transect are measured exactly; and (iv) groups are counted accurately, at least when they are close to the transect (Thomas et al., 2010). We counted wildlife species that were large and conspicuous, so the first assumption was easily met. Here distance from observer-to-animal was measured using laser rangefinders, thus supporting the second assumption.
Transect direction and angle between animal and observer were determined from an analog handheld compass, thus supporting assumption three. Perpendicular distance to the transect was calculated using the angle between the transect and the animal and radial distance from observer to animal. Finally, the fourth assumption was met by recording length of censuses routes in kilometer from the car odometer.

To obtain distribution data, each wildlife species location via distance sampling was determined using a Garmin GPS. Wildlife location data was superimposed into the map of the area using ARCMAP to show distribution (ESRI, 2015). In addition to census routes, walking routes were also designed to cover areas that were not accessible with a vehicle. GPS locations and wildlife species locations were obtained in these routes by walking almost $10 \mathrm{~km}$ in per route in week. Finally, all water points and permanent river courses were marked using GPS. Because both the total number of wildlife species sighted along transects at each study site and the area of each site varied, the analyses across space and time with respect to the number of wildlife, bomas (human settlements) and livestock encountered per transect in each study site and for each monthly census was converted into densities per $\mathrm{km}^{2}$.

\subsection{Data analysis}

Due to some herbivore wildlife species occurring in very low numbers in certain land use types for distance calculations, they were classified into different groups related to 


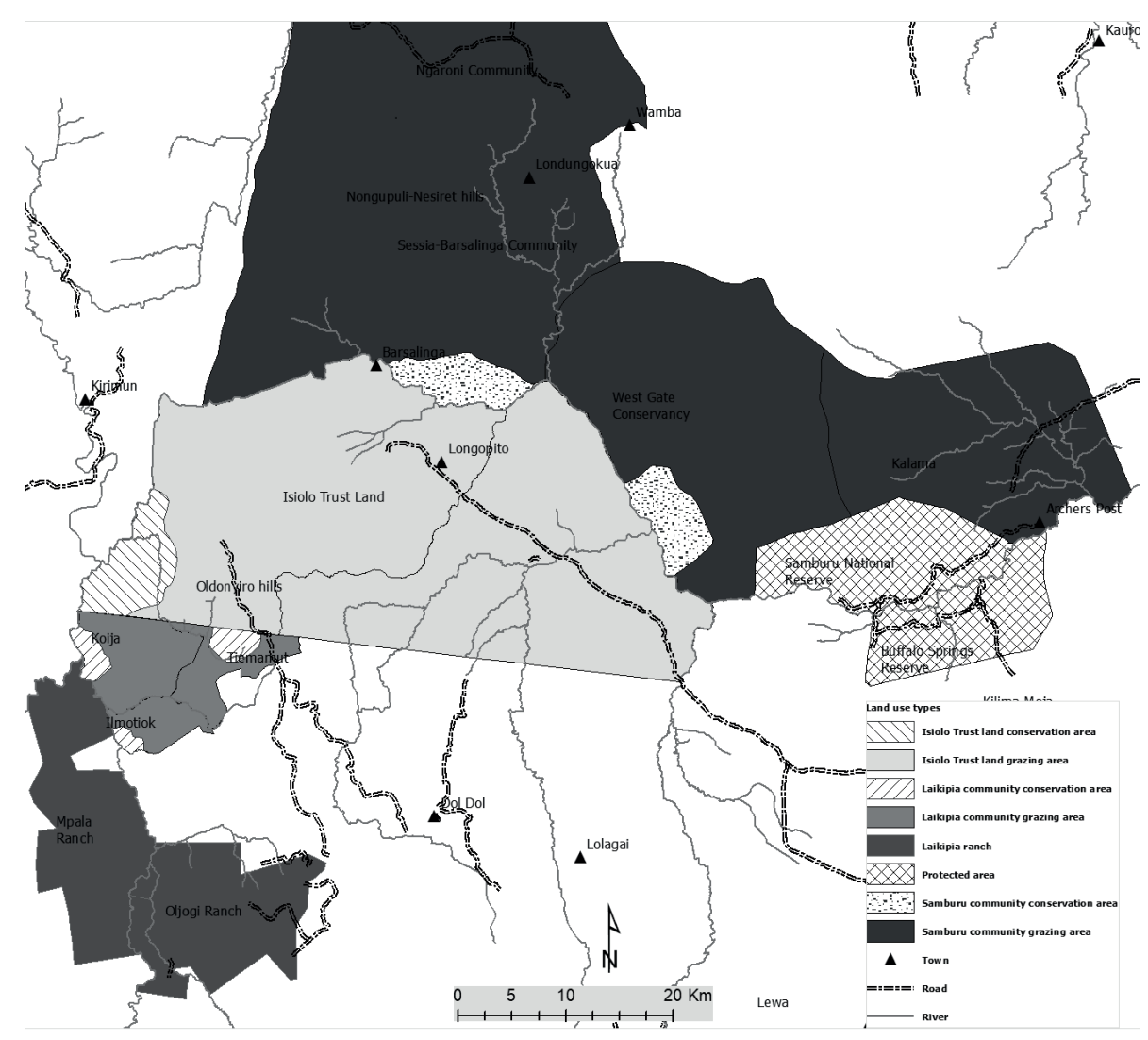

Fig. 2. Land use types occurring in Samburu-Laikipia landscape (modified from Ihwagi et al., 2015).

feeding guilds as; 1) Larger grazers which included buffalo (Syncerus caffer), elands (Taurotragus oryx), plain zebra (Equus burchellii), Grevy's zebra (Equus grevyi), waterbuck (Kobus ellipsiprymnus), Jackson's heartbeast (Alcelaphus buselaphus) and Oryx (Oryx gazelle), 2) Small Grazers included Grants gazelle (Nanger granti), Thomson gazelle (Gazella thomsonii) and Warthog (Phacochoerus africanus) though regarded omnivorous, 3) Browsers that included Gerenuk (Litocranius walleri), dikdik (Madoqua kirkii), Greater Kudu ((Tragelaphus strepsiceros) and Giraffe (Giraffa camelopardalis reticulata), 4) Mixed browsers/grazers which included the Impala (Aepyceros melampus), lesser Kudu (Tragelaphus imberbis) and Elephant (Loxodonta Africana) and 5) Ostrich (Struthio molybdophanes) was put under its own class as it is a bird species and due to its large size, could be easily counted with other wildlife species.

To analyze herbivore groups density, exact perpendicular distances were used and the wildlife groups or other animals treated as clusters. For each census visit and on each census route, we evaluated half-normal, hazard and uniform models with cosine and simple polynomial adjustments and chose the final model based on a minimum AIC value on Distance Program 6.0 release 2 (Akaike, 1974; Thomas et al., 2010). For this analysis, half - normal with cosine adjustment or hazard rate with simple polynomial adjustments produced lowest AIC value and were desired. Ostrich distribution was not tested due to low sample size. Distance to the nearest water point to animal or group of animals was determined using ARCMAP (ESRI, 2015)

Correlation analysis was conducted to assess the relationship between human activities and distance to the nearest water on wildlife density in both dry and wet season as shown in Appendix 1 (a) and (b). Differences in in three samples or more was tested using One-way Analysis of Variance (ANOVA), at 5\% level of significance using JMPRO Version 14 Statistical Package. When models showed significant differences, differences in means were compared using Student t-test LSM test.

\section{Results}

\subsection{Wildlife distribution}

Herbivore wildlife groups censored distribution and abundances was highly dependent on the land use type both in wet and dry season for total wildlife $\left(\chi^{2}=80.53\right.$, p < $0.001,3 \mathrm{df})$, small grazers $\left(\chi^{2}=12.75, \mathrm{df}=3, \mathrm{p}<0.01\right)$, large grazers $\left(\chi^{2}=167.99, \mathrm{df}=3, \mathrm{p}<0.001\right)$, browsers $\left(\chi^{2}=17.04, \mathrm{df}=3 \mathrm{p}<0.001\right)$ and mixed browsers/grazers $\left(\chi^{2}=9.82\right.$, df $\left.=3, \mathrm{p}<0.015\right)$.

\subsection{Impact of seasons on wildlife groups abundances in different land use types}

Different herbivore wildlife groups densities were compared between dry and wet seasons across different land use encountered in Samburu-Laikipia landscape (Table 1). Large grazers abundance showed significant difference between 
different land uses in dry season $\left(\mathrm{F}_{3,97}=9.24, \mathrm{p}<0.001\right)$. This difference was highly contributed by PAs mean (5.61 \pm 1.70 ) compared to CGAs. LR also had a higher though significantly different from the others.

Small grazers showed significant differences between land use in dry season $\left(\mathrm{F}_{3,97}=44.02, \mathrm{p}<0.001\right)$. PAs had higher mean density significantly different from LR, CCAs and CGAs while LR had higher mean density significantly different from CCAs and CGAs. Smaller grazers also varied significantly between land uses in wet season $\left(\mathrm{F}_{3,47}=7.84\right.$, $\mathrm{p}<0.001$ ). LR had significant high mean density than CCAs and CGAs while PAs had a high significant mean density than CGAs.

Browser's densities varied between different land uses in dry season $\left(\mathrm{F}_{3,97}=14.02, \mathrm{p}<0.001\right)$ with PAs mean being significantly different from LRs, CCAs and CGAs. In wet season, abundance of browsers also varied significantly between the different land uses $\left(\mathrm{F}_{3,47}=12.31\right.$, $\left.\mathrm{p}<0.001\right)$ where PAs mean was significantly different from CCAs, LRs and CGAs (Table 1). Significant differences for mixed browsers/grazers were also observed between the different land uses in dry season $\left(\mathrm{F}_{3,97}=32.33, \mathrm{p}<0.001\right)$. PAs mean for mixed browsers/grazers was significantly different from CCAs, CGAs and LRs (Table 1). LR also had a high mean that was significantly different from CGAs (Table 1).

In the dry season, Ostrich density varied significantly between different land use $\left(\mathrm{F}_{3,98}=18.26, \mathrm{p}<0.001\right)$ with mean density in CGAs being significantly different from LR

Table 1: Seasonal variations of wildlife abundances (number $/ \mathrm{km}^{2} \pm \mathrm{SE}$ ) in different land uses of Samburu-Laikipia landscape.

\begin{tabular}{|c|c|c|c|c|c|c|}
\hline \multirow{2}{*}{ Wildlife Group } & \multirow{2}{*}{ Weather season } & \multicolumn{4}{|c|}{ Mean abundance (number $/ \mathrm{km}^{2} \pm \mathrm{SE}$ ) } & \multirow[t]{2}{*}{ ANOVA } \\
\hline & & CCAs & CGAs & LR & PAs & \\
\hline \multirow{2}{*}{ Large grazers } & Dry & $2.37 \pm 0.42^{\mathrm{c}}$ & $0.19 \pm 0.11^{\mathrm{d}}$ & $3.28 \pm 0.41^{\mathrm{b}}$ & $5.61 \pm 1.70^{\mathrm{a}}$ & $\mathrm{F} 3,97=43.91 * * *$ \\
\hline & Wet & $1.54 \pm 0.42^{\mathrm{c}}$ & $6.29 \pm 6.18^{b}$ & $1.13 \pm 0.18^{\mathrm{b}}$ & $6.21 \pm 1.36^{\mathrm{a}}$ & $\mathrm{F} 3,47=1.96 \mathrm{NS}$ \\
\hline \multirow{2}{*}{ Small grazers } & Dry & $1.47 \pm 0.24^{c}$ & $0.35 \pm 0.07^{\mathrm{d}}$ & $5.69 \pm 0.40^{\mathrm{b}}$ & $8.84 \pm 1.27^{\mathrm{a}}$ & $\mathrm{F} 3,97=102.57^{* * *}$ \\
\hline & Wet & $0.98 \pm 0.24^{c}$ & $0.22 \pm 0.03^{\mathrm{d}}$ & $4.56 \pm 1.25^{\mathrm{a}}$ & $3.20 \pm 1.35^{\mathrm{b}}$ & $\mathrm{F} 3,47=13.09 * * *$ \\
\hline \multirow{2}{*}{ Browsers } & Dry & $1.14 \pm 0.19^{\mathrm{b}}$ & $0.76 \pm 0.10^{\mathrm{b}}$ & $1.04 \pm 0.48^{\mathrm{b}}$ & $2.40 \pm 0.25^{\mathrm{a}}$ & $\mathrm{F} 3,97=15.53^{* * *}$ \\
\hline & Wet & $0.99 \pm 0.24^{\mathrm{b}}$ & $0.76 \pm 0.30^{\mathrm{b}}$ & $0.03 \pm 0.03^{c}$ & $5.79 \pm 1.48^{a}$ & $\mathrm{~F} 3,47=20.74 * * *$ \\
\hline \multirow{2}{*}{$\begin{array}{l}\text { Mixed Browser / } \\
\text { grazers }\end{array}$} & Dry & $2.26 \pm 0.43^{\mathrm{c}}$ & $0.07 \pm 0.04^{\mathrm{d}}$ & $4.26 \pm 0.97^{\mathrm{b}}$ & $7.47 \pm 1.12^{\mathrm{a}}$ & $\mathrm{F} 3,98=79.49 * * *$ \\
\hline & Wet & $1.04 \pm 0.20^{\mathrm{b}}$ & $0.20 \pm 0.19^{c}$ & $2.04 \pm 0.50^{\mathrm{b}}$ & $6.89 \pm 1.94^{\mathrm{a}}$ & $\mathrm{F} 3,41=35.85^{* * *}$ \\
\hline \multirow{2}{*}{ Ostrich } & Dry & $0.02 \pm 0.01^{\mathrm{b}}$ & $0.26 \pm 0.03^{\mathrm{a}}$ & $0.008 \pm 0.003^{\mathrm{b}}$ & $0.20 \pm 0.05^{\mathrm{a}}$ & $\mathrm{F} 3,98=18.26^{* * *}$ \\
\hline & Wet & $0.002 \pm 0.001^{\mathrm{c}}$ & $0.34 \pm 0.05^{\mathrm{b}}$ & $0.05 \pm 0.05^{c}$ & $1.39 \pm 0.56^{\mathrm{a}}$ & $\mathrm{F} 3,47=10.84^{* * *}$ \\
\hline \multirow{2}{*}{ Total wildlife } & Dry & $4.95 \pm 1.16^{\mathrm{b}}$ & $2.32 \pm 0.50^{c}$ & $13.16 \pm 1.32^{\mathrm{a}}$ & $8.40 \pm 1.56^{\mathrm{b}}$ & $\mathrm{F} 3,98=20.87 * * *$ \\
\hline & Wet & $2.93 \pm 0.72^{\mathrm{c}}$ & $4.63 \pm 1.25^{\mathrm{b}}$ & $8.19 \pm 2.51^{\mathrm{a}}$ & $2.31 \pm 0.34^{\mathrm{c}}$ & $\mathrm{F} 3,47=2.53 \mathrm{NS}$ \\
\hline
\end{tabular}

NS $=$ Not significant, $\mathrm{p}>0.05, *=$ Significant difference $\mathrm{p}<0.05, * *=$ Significant difference $\mathrm{P}<0.01, * * *=$ Significant difference $\mathrm{p}<0.001$, CCAs $=$ Community Conservation Areas, CGAs = Community Grazing Areas, PAs = Protected Areas and LR = Laikipia Ranch (Mpala)

and CCAs while PAs mean was significantly different from LRs and CCAs. Significant differences were also observed in wet season $\left(\mathrm{F}_{3,47}=10.84, \mathrm{p}<0.001\right)$ with PAs significantly different from LRs, CCAs and CGAs while CGAs had the second highest mean significantly different from LR and CCAs. Total wildlife densities varied significantly between different land uses in dry season $\left(\mathrm{F}_{3,97}=17.49\right.$, $\left.\mathrm{p}<0.001\right)$ where LR mean was significantly different from CCAs, CGAs and PAs. PAs also had a high total wildlife mean density significantly different from CGAs (Table 1).

\subsection{Impacts of livestock, human settlement and water on differ- ent wildlife groups abundances}

Cattle abundance had negative significant correlations with browsers in wet season $\left(\mathrm{r}^{2}=-0.36, \mathrm{p}<0.05\right)$ and mixed browser/grazers $\left(r^{2}=-0.35, p<0.01\right)$. Shoats abun- dance had negative significant correlation with large grazers $\left(\mathrm{r}^{2}=-0.25, \mathrm{p}<0.05\right)$, smaller grazers $\left(\mathrm{r}^{2}=-0.41, \mathrm{p}<\right.$ $0.001)$ and mixed browser/grazers $\left(r^{2}=-0.38, p<0.001\right)$ during dry season. In wet season, shoats showed significant negative correlations with small grazers $\left(\mathrm{r}^{2}=-0.36, \mathrm{p}<\right.$ $0.001)$, browsers $\left(\mathrm{r}^{2}=-0.33, \mathrm{p}<0.05\right)$, mixed browser/ grazers $\left(\mathrm{r}^{2}=-0.45, \mathrm{p}<0.01\right)$ and significant positive correlation for total wildlife density $\left(r^{2}=0.32\right.$, $\left.p<0.01\right)$.

Negative significant correlation was observed between total livestock density with small grazers density $\left(\mathrm{r}^{2}=\right.$ $-0.24, \mathrm{p}<0.05)$ and mixed browser/grazers $\left(\mathrm{r}^{2}=-0.29\right.$, $\mathrm{p}<0.01$ ). In wet season, significant negative correlations were observed for small grazers $\left(r^{2}=-0.38, p<0.01\right)$, browsers $\left(\mathrm{r}^{2}=-0.38, \mathrm{p}<0.01\right)$ and mixed browser/grazers $\left(r^{2}=-0.49, p<0.001\right)$. In dry season, human settlement (bomas density) had negative significant correlations were 
observed on large grazers $\left(\mathrm{r}^{2}=-0.47, \mathrm{p}<0.001\right)$, browsers $\left(\mathrm{r}^{2}=-0.43, \mathrm{p}<0.001\right)$ and mixed browser/grazers $\left(\mathrm{r}^{2}=\right.$ $-0.44, \mathrm{p}<0.001)$. Significant negative correlations were observed for large grazers $\left(\mathrm{r}^{2}=-0.32, \mathrm{p}<0.01\right)$, browsers $\left(\mathrm{r}^{2}=-0.26, \mathrm{p}<0.05\right)$ and mixed browser/grazers $\left(\mathrm{r}^{2}=\right.$ $-0.52, \mathrm{p}<0.001)$ with human settlement in wet season.

\section{Discussion}

The distribution and abundances of wildlife in SamburuLaikipia landscape varied between the land use types depending on prevailing weather season. In both dry and wet season, PAs, LRs and CCAs in that order maintained high abundance of most wildlife groups while CGAs maintained low abundances. The only exception observed was for large grazers which did not vary significantly between the different land use types during wet season and whose density increased highly on CGAs. This was probably due to large numbers of large grazers especially Grevy's zebra's moving from dry grazing areas into CGAs to take advantage of high quality short annual grass swards due rainfall and heavy livestock grazing. During wet season, resources are not be limiting and therefore can be shared with livestock. At the same time, large herbivores abundance reduced in numbers in community conservation areas and in Laikipia ranches. Due to the large number of grazers in wet season both wildlife and livestock in CGAs, resources get depleted fast and reach a critical level in dry season where both wildlife and livestock move out of in such for abundant food resources patch. Another varying observation was for smaller grazer's abundance that had high abundance in LRs compared to other land use types in wet season. In dry season, total wildlife abundances were also high in LRs which was due to movement of wildlife from neighbouring areas. Ostrich behaved differently from other wildlife groups where their abundance was high in community grazing areas during dry weather and increased in protected areas during wet season. Browsers and grazers/mixed browsers did not change much over different weather seasons and remained high in PAs, LRs and CCAs compared to community grazing areas. This can be attributed to their shy nature to human activities and therefore, they have little movements between the different land uses.

Whereas there is an agreement that humans, livestock and wildlife can coexists in arid and semi-arid savanna landscape, through complementary facilitation (Odadi et al., 2011; du Toit, 2011), many authors are also in agreement that livestock do impact negatively on wildlife and their habitats (Sitters et al., 2009; Ogutu et al., 2011). The direct impacts of human's activities and livestock in an ecosystem is through wildlife habitat modification and overgrazing to degradation and wildlife losses. In CGAs and CCAs were observed to have reduced grass cover, grass height, percentage perennial grasses and herbaceous layer biomass compared to PAs and LRs. In addition, livestock is assumed to directly compete and displace wildlife thereby reducing resource availability especially in low rainfall months (Sitters et al., 2009). This study observed negative influences of livestock groups on all wildlife groups in both wet and dry seasons suggesting that wildlife avoided livestock or areas with livestock and human activities.

The observation that human activities (livestock keeping and human settlements) have diverse negative impacts on wildlife species and their habitats has been documented by different authors (Meyer and Turner, 1992; Dunham et al., 2003; Hebblewhite and Merrill, 2007; MacGregor-Fors et al., 2011). Human settlement affect wildlife by changing animals perceived landscape by modifying vegetation composition and structure while curtailing animal movements and influencing animal interaction with the environment. Different wildlife feeding guilds behave differently to human landscape modification (Worden et al., 2003) as observed by this study. On the converse that small bodied mammals adapt easily to land-use changes (Maitima et al., 2009), this study found that they reduced in human dominated areas in both dry and wet season compared to conservation friendly areas in Samburu-Laikipia landscape.

\section{Conclusions}

With increasing human population nowadays, more wild land is being converted into other land uses types for the benefit of human kinds. This will greatly reduce the abundance of wildlife in these arid and semi-arid regions of the world. Already steep declines in wildlife populations have been noticed within Kenyan rangelands associated with land use changes. Wildlife declines in these lands is not desirable as they are important to conservation of biodiversity and hold social-economic potential that is important for human survival if properly used through tourism in addition to other lenient uses. However, this is not happening due to short-term needs for local communities where they attach their immediate monetary requirements into any venture. For any economic venture with biodiversity conservation to succeed, immediate, needs for communities have to be articulated. This calls for joint understanding between conservation bodies, government and communities to look at all aspects affecting the survival of biodiversity and community's needs.

Our study indicated that land use type had influence on distribution and abundance of herbivore wildlife groups in favour of conservation friendly areas. Likewise, livestock and human settlements had negative influence on the on the distribution and abundances of herbivorous wildlife species while distance to water had little influences apart on large herbivores. There is a need to control the level of human's activities in arid and semi-arid savanna especially development, livestock numbers and use of natural resources in order to arrest this trend of losing biodiversity. In addition, improvision of surface water is necessary to increase the quality of habitats and especially for all wildlife. Though this is one of the main goals for the formation of the numer- 
ous community conservancies in the country in this landscape, there is a need to monitor, control and manage their usage so that the objective of biodiversity conservation is achieved. This will require a balancing act where communities are well involved such that they become part and parcel of decision making. With support from local communities, development should be sustainable where human activities and livestock stocking rates are checked in order to maintain both wildlife and local communities' coexistence.

\section{Acknowledgements}

We highly appreciate the assistance from Princeton University for financial support, analysis software's and field logistics. Prof. Dan Rubenstein did marvelous job in providing field advice and making funds were available for this study from Princeton University (Grant no. NSF IIS-CXT). In the field, assistance from Nicolas and Rikapo is highly appreciated. Mpala Ranch and Research Centre provided a working bench and we are grateful. We highly acknowledge Samburu community, Laikipia community, Samburu National Reserve and Buffalo Springs National Reserve for allowing us to conduct the research on their land.

\section{References}

Akaike, H. (1974). A new look at the statistical model identification. IEEE Transactions on Automatic Control, 19(6), 716-723. https://doi. org/10.1109/TAC.1974.1100705

County Government of Laikipia (2018). Laikipia County Integrated Development Plan 2018-2022, 217 pgs.

County Government of Samburu (2018). Samburu County Integrated Development Plan 2018-2022, 399 pgs.

Dunham, K. M., Robertson, E. F., \& Swanepoel, C. M. (2003). Population decline of tsessebe antelope (Damaliscus lunatus lunatus) on a mixed cattle and wildlife ranch in Zimbabwe. Biological Conservation, 113(1), 111-124. https://doi.org/10.1016/S0006-3207(02)00354-3

du Toit, J. T. (2011). Coexisting with Cattle. Science, 333(6050), 1710-1711. https://doi.org/10.1126/science.1212452

Du Toit, J. T., \& Cumming, D. H. M. (1999). Functional significance of ungulate diversity in African savannas and the ecological implications of the spread of pastoralists. Biodiversity and Conservation, 8(12), 1643-1661. https://doi.org/10.1023/A:1008959721342

ESRI, (2015). ArcGIS for Desktop. ESRI INC., USA.

Hebblewhite, M., \& Merrill, E. (2007). Modelling wildlife-human relationships for social species with mixed-effects resource selection models: Mixed-effect resource selection models. Journal of Applied Ecology, 45(3), 834-844. https://doi.org/10.1111/j.1365-2664.2008.01466.x

Holdo, R. M., Holt, R. D., \& Fryxell, J. M. (2009). Opposing Rainfall and Plant Nutritional Gradients Best Explain the Wildebeest Migration in the Serengeti. The American Naturalist, 173(4), 431-445. https://doi.org/10.1086/597229

Hopcraft, D. (2000). Wildlife land use and the great experiment. In: Prins, H.H.T., Grootenhuis, J.G., Dolan, T.T. (Eds.), Wildlife Conservation by Sustainable Use. Kluwer Academic Publishers, Boston, pp. 267-276.
Ihwagi, F. W., Wang, T., Wittemyer, G., Skidmore, A. K., Toxopeus, A. G., Ngene, S., King, J., Worden, J., Omondi, P., \& Douglas-Hamilton, I. (2015). Using Poaching Levels and Elephant Distribution to Assess the Conservation Efficacy of Private, Communal and Government Land in Northern Kenya. PLOS ONE, 10(9), e0139079. https://doi.org/10.1371/journal.pone.0139079

Lovett, J. C., Barnard, P., \& Midgley, G. F. (2005). National Climate Change Conference in South Africa. African Journal of Ecology, 43(4), 279-281. https://doi.org/10.1111/j.1365-2028.2005.00608.x

Maitima, M.J., Mugatha, M.S., Reid, S.R. , Gachimbi, N.L., Majule, A., Lyaruu, H., Pomery, D., Mathai, S. \& Mugisha, S. (2009). The linkages between land use change, land degradation and biodiversity across East Africa. African Journal of Environmental Science and echnology, 3 (10): pp. 310-325. Google scholar

MacGregor-Fors, I., Morales-Pérez, L., \& Schondube, J. E. (2011). Does size really matter? Species-area relationships in human settlements: Species-area relationships in human settlements. Diversity and Distributions, 17(1), 112121. https://doi.org/10.1111/j.1472-4642.2010.00714.x

Meyer, W. B., \& Turner, B. L. (1992). Human Population Growth and Global Land-Use/Cover Change. Annual Review of Ecology and Systematics, 23(1), 39-61. https://doi.org/10.1146/annurev.es.23.110192.000351

Nelson, F. (2012). Natural conservationists? Evaluating the impact of pastoralist land use practices on Tanzania's wildlife economy. Pastoralism: Research, Policy and Practice, 2(1), 15. https://doi.org/10.1186/2041-7136$2-15$

Odadi, W. O., Karachi, M. K., Abdulrazak, S. A., \& Young, T. P. (2011). African Wild Ungulates Compete with or Facilitate Cattle Depending on Season. Science, 333(6050), 1753-1755. https://doi.org/10.1126/science.1208468

Ogutu, J. O., Owen-Smith, N., Piepho, H.-P., \& Said, M. Y. (2011). Continuing wildlife population declines and range contraction in the Mara region of Kenya during 1977-2009: Extreme wildlife declines in Masai Mara. Journal of Zoology, 285(2), 99-109. https://doi.org/10.1111/j.1469-7998.2011.00818.x

Ogutu, J. O., Piepho, H.-P., Said, M. Y., Ojwang, G. O., Njino, L. W., Kifugo, S. C., \& Wargute, P. W. (2016). Extreme Wildlife Declines and Concurrent Increase in Livestock Numbers in Kenya: What Are the Causes? PLOS ONE, 11(9), e0163249. https://doi.org/10.1371/journal.pone.0163249

Plumptre, A. J. (2000). Monitoring mammal populations with line transect techniques in African forests. Journal of Applied Ecology, 37(2), 356-368. https://doi.org/10.1046/j.1365-2664.2000.00499.x

Pratt, D. J., Greenway, P. J., \& Gwynne, M. D. (1966). A Classification of East African Rangeland, with an Appendix on Terminology. The Journal of Applied Ecology, 3(2), 369. https://doi.org/10.2307/2401259

Prins, H.H.T. (2000). Competition between wildlife and livestock in Africa. In: Prins, H.H.T., Grootenhuis, J.G., Dolan, T.T. (Eds.), Wildlife conservation by sustainable use. Kluwer Academic Publishers, Boston, pp. 5-80.

Sitters, J., Heitkönig, I. M. A., Holmgren, M., \& Ojwang', G. S. O. (2009). Herded cattle and wild grazers partition water but share forage resources during dry years in East African savannas. Biological Conservation, 142(4), 738-750. https://doi.org/10.1016/j.biocon.2008.12.001

Thomas, L., Buckland, S.T., Rexstad, E.A., Laake, J.L., Strindberg, S., Hedley, S.L., Bishop, J.R.B., Marques, T.A., and Burnham, K.P. (2010). Distance software: design and analysis of distance sampling surveys for estimating population size. Journal of Applied Ecology 2010, 47: 5-14, https://doi. org/10.1111/j.1365-2664.2009.01737.x

Vetter, S. (2005). Rangelands at equilibrium and non-equilibrium: Recent developments in the debate. Journal of Arid Environments, 62(2), 321-341. https://doi.org/10.1016/j.jaridenv.2004.11.015

Worden, J., Reid, R., \& Gichohi, H. (2003). Land-use impacts on large wildlife and livestock in the swamps of the greater Amboseli ecosystem, Kajiado District, Kenya. Land Use Change Impacts and Dynamics (LUCID) Project, Report No. 27. International Livestock Research Institute, Nairobi, Kenya. Google scholar 
Appendix 1 (a): Correlation analysis between human settlement, livestock and water on wildlife abundances during dry weather season in SamburuLaikipia landscape.

\begin{tabular}{|c|c|c|c|c|c|c|c|c|c|c|c|}
\hline & & $\begin{array}{l}\text { Total } \\
\text { livestock }\end{array}$ & Shoats & Cattle & $\begin{array}{l}\text { Near } \\
\text { water }\end{array}$ & $\begin{array}{l}\text { Human } \\
\text { settlement }\end{array}$ & $\begin{array}{l}\text { Large } \\
\text { grazers }\end{array}$ & $\begin{array}{l}\text { Small } \\
\text { grazers }\end{array}$ & Ostrich & Browsers & $\begin{array}{l}\text { Mixed brows- } \\
\text { er/grazers }\end{array}$ \\
\hline \multicolumn{12}{|l|}{ Total livestock } \\
\hline \multirow{2}{*}{ Shoats } & $\mathrm{r}^{2}$ & $0.61^{* * * *}$ & & & & & & & & & \\
\hline & Count & 101 & & & & & & & & & \\
\hline \multirow{2}{*}{ Cattle } & $\mathrm{r}^{2}$ & $0.22^{*}$ & $0.25^{*}$ & & & & & & & & \\
\hline & Count & 101 & 101 & & & & & & & & \\
\hline \multirow{2}{*}{ Near water } & $\mathrm{r}^{2}$ & $0.16 \mathrm{NS}$ & $0.14 \mathrm{NS}$ & $0.12 \mathrm{NS}$ & & & & & & & \\
\hline & Count & 100 & 100 & 100 & & & & & & & \\
\hline \multirow{2}{*}{$\begin{array}{l}\text { Human } \\
\text { settlement }\end{array}$} & $\mathrm{r}^{2}$ & $-0.10 \mathrm{NS}$ & $-0.26^{*}$ & $-0.07 \mathrm{NS}$ & $0.20^{* * *}$ & & & & & & \\
\hline & Count & 98 & 98 & 98 & 249 & & & & & & \\
\hline \multirow{2}{*}{ Large grazers } & $\mathrm{r}^{2}$ & $-0.16 \mathrm{NS}$ & $-0.25^{*}$ & $-0.03 N S$ & $0.26^{* *}$ & $-0.47 * * *$ & & & & & \\
\hline & Count & 101 & 101 & 101 & 100 & 98 & & & & & \\
\hline \multirow{2}{*}{ Small grazers } & $\mathrm{r}^{2}$ & $-0.24 *$ & $-0.41 * * *$ & $-0.12 \mathrm{NS}$ & $-0.27 * *$ & -0.21 & $0.33 * * *$ & & & & \\
\hline & Count & 101 & 101 & 101 & 100 & 98 & 101 & & & & \\
\hline \multirow{2}{*}{ Ostrich } & $\mathrm{r}^{2}$ & $0.07 \mathrm{NS}$ & $0.13 \mathrm{NS}$ & $-0.14 \mathrm{NS}$ & $0.22^{*}$ & $0.20 \mathrm{NS}$ & $-0.14 \mathrm{NS}$ & $0.03 \mathrm{NS}$ & & & \\
\hline & Count & 101 & 101 & 101 & 100 & 98 & 101 & 101 & & & \\
\hline \multirow{2}{*}{ Browsers } & $\mathrm{r}^{2}$ & $-0.10 \mathrm{NS}$ & $-0.15 \mathrm{NS}$ & $-0.12 \mathrm{NS}$ & $-0.24 *$ & $-0.43^{* * *}$ & 0.30 ** & $0.39 * * *$ & $0.01 \mathrm{NS}$ & & \\
\hline & Count & 101 & 101 & 101 & 100 & 99 & 101 & 101 & 101 & & \\
\hline \multirow{2}{*}{$\begin{array}{l}\text { Mixed browser/ } \\
\text { grazers }\end{array}$} & $\mathrm{r}^{2}$ & $-0.29 * *$ & $-0.38 * * *$ & -0.09 & $-0.31 * *$ & $-0.44 * * *$ & $0.76^{* * *}$ & $0.66 * * *$ & $-0.11 \mathrm{NS}$ & $0.43^{* * *}$ & \\
\hline & Count & 101 & 101 & 101 & 101 & 99 & 101 & 101 & 102 & 101 & \\
\hline
\end{tabular}

NS $=$ Not significant, $\mathrm{p}>0.05,{ }^{*}=$ Significant difference $\mathrm{p}<0.05,{ }^{* *}=$ Significant difference $\mathrm{P}<0.01,{ }^{* * *}=$ Significant difference $\mathrm{p}<0.001$ 
Appendix 1 (b): Correlation analysis between human settlement, livestock and water on wildlife abundances during wet weather season in SamburuLaikipia landscape.

\begin{tabular}{|c|c|c|c|c|c|c|c|c|c|c|c|}
\hline & & $\begin{array}{l}\text { Total } \\
\text { livestock }\end{array}$ & Shoats & Cattle & $\begin{array}{l}\text { Near } \\
\text { water }\end{array}$ & $\begin{array}{l}\text { Human } \\
\text { settlement }\end{array}$ & $\begin{array}{l}\text { Large } \\
\text { grazers }\end{array}$ & $\begin{array}{l}\text { Small } \\
\text { grazers }\end{array}$ & Ostrich & Browsers & $\begin{array}{l}\text { Mixed brows- } \\
\text { er/grazers }\end{array}$ \\
\hline \multicolumn{12}{|l|}{ Total livestock } \\
\hline \multirow{2}{*}{ Shoats } & $\mathrm{r} 2$ & $0.68 * * *$ & & & & & & & & & \\
\hline & Count & 51 & & & & & & & & & \\
\hline \multirow{2}{*}{ Cattle } & $\mathrm{r} 2$ & $0.22 \mathrm{NS}$ & $0.19 \mathrm{NS}$ & & & & & & & & \\
\hline & Count & 51 & 51 & & & & & & & & \\
\hline \multirow{2}{*}{ Near water } & $\mathrm{r} 2$ & $0.39 *$ & $0.40 *$ & $0.22 \mathrm{NS}$ & & & & & & & \\
\hline & Count & 50 & 50 & 50 & & & & & & & \\
\hline \multirow{2}{*}{$\begin{array}{l}\text { Human } \\
\text { settlement }\end{array}$} & r2 & $-0.40 * * *$ & $-0.42^{*}$ & $-0.07 \mathrm{NS}$ & $-0.08 \mathrm{NS}$ & & & & & & \\
\hline & Count & 50 & 50 & 50 & 126 & & & & & & \\
\hline \multirow{2}{*}{ Large grazers } & $\mathrm{r} 2$ & $-0.21 \mathrm{NS}$ & $-0.16 N S$ & $-0.18 \mathrm{NS}$ & $0.01 \mathrm{NS}$ & $-0.32 * *$ & & & & & \\
\hline & Count & 51 & 51 & 51 & 50 & 50 & & & & & \\
\hline \multirow{2}{*}{ Small grazers } & $\mathrm{r} 2$ & $-0.39 * *$ & $-0.38 *$ & $-0.20 \mathrm{NS}$ & $-0.24 \mathrm{NS}$ & $-0.22 \mathrm{NS}$ & $-0.03 N S$ & & & & \\
\hline & Count & 51 & 51 & 51 & 50 & 50 & 51 & & & & \\
\hline \multirow{2}{*}{ Ostrich } & $\mathrm{r} 2$ & $-0.18 \mathrm{NS}$ & $-0.14 N S$ & $-0.18 \mathrm{NS}$ & $0.27 \mathrm{NS}$ & $0.08 \mathrm{NS}$ & $-0.03 N S$ & $-0.21 \mathrm{NS}$ & & & \\
\hline & Count & 51 & 51 & 51 & 50 & 50 & 51 & 51 & & & \\
\hline \multirow{2}{*}{ Browsers } & $\mathrm{r} 2$ & $-0.38 * *$ & $-0.32 *$ & $-0.35^{* *}$ & $0.04 \mathrm{NS}$ & $-0.26 *$ & $0.34 *$ & $0.21 \mathrm{NS}$ & $0.26 \mathrm{NS}$ & & \\
\hline & Count & 51 & 51 & 51 & 50 & 50 & 51 & 51 & 51 & & \\
\hline \multirow{2}{*}{$\begin{array}{l}\text { Mixed browser/ } \\
\text { grazers }\end{array}$} & $\mathrm{r} 2$ & $-0.49 * * *$ & $-0.45^{* * *}$ & $-0.35^{*}$ & $-0.22 \mathrm{NS}$ & $-0.52 * * *$ & $0.23 \mathrm{NS}$ & $0.72 * * *$ & $-0.33^{*}$ & $0.62 * * *$ & \\
\hline & Count & 45 & 45 & 45 & 45 & 44 & 45 & 45 & 45 & 45 & \\
\hline
\end{tabular}

NS $=$ Not significant, $\mathrm{p}>0.05, *=$ Significant difference $\mathrm{p}<0.05, * *=$ Significant difference $\mathrm{P}<0.01, * * *=$ Significant difference $\mathrm{p}<0.001$ 